\title{
Effect of Foliar Application of Methyl Jasmonate and Extracts of Juniper and Sagebrush on Essential Oil Yield and Composition of 'Native' Spearmint
}

\author{
Valtcho D. Zheljazkov ${ }^{1}$ \\ University of Wyoming, Sheridan Research and Extension Center, 663 \\ Wyarno Road, Sheridan, WY 82801
}

Tess Astatkie

Dalhousie University, Faculty of Agriculture, 50 Pictou Road, P.O. Box 550, Truro, NS B2N 5E3, Canada

\section{Ekaterina Jeliazkova}

University of Wyoming, Sheridan Research and Extension Center, 663 Wyarno Road, Sheridan, WY 82801

Additional index words. Mentha spicata, Rocky Mountain juniper, big sagebrush, Tween20, foliar application, essential oil content, essential oil composition, carvone

\begin{abstract}
Spearmint (Mentha spicata L.) is a major essential oil crop in the United States. Developing means for increased biomass and oil yields and increased concentrations of carvone would be beneficial for the essential oil industry. A field experiment was conducted to study the effect of foliar application treatments [water (control), water + Tween20, sagebrush essential oil + Tween20, sagebrush water extract, juniper essential oil + Tween20, juniper water extract, and methyl jasmonate] on 'Native' spearmint essential oil content, shoot fresh weight, oil yield, and oil composition. The essential oil content was low in the water + Tween20 and in juniper essential oil (EO) + Tween20 treatments and high in the juniper water extract and in methyl jasmonate (MJ) treatments; however, neither of these were different from the water control or from the sagebrush EO + Tween 20. Biomass fresh weight was lower in the sagebrush water extract (SWE) and in the juniper water extract (JWE) relative to the water control. The application of juniper $\mathrm{EO}+\mathrm{Tween} 20$ reduced the concentration of carvone in the oil relative to the water control or to the water + Tween20 treatment. The sagebrush water extract, juniper EO + Tween20, juniper water extract, and MJ increased the concentrations of beta-caryophyllene relative to the water treatment. The concentration of trans-beta-farnesene was lower in the control water treatment and higher in all other treatments. Also, with the exception of sagebrush EO + Tween20, all treatments increased the concentration of germacrene $D$ relative to the water control but not relative to water + Tween20. This study demonstrated that foliar application of sagebrush EO, sagebrush water extract, juniper EO, or juniper water extract to 'Native' spearmint may affect the essential oil profile of spearmint essential oil. Some of the treatments increased the concentrations of beta-caryophyllene, trans-beta-farnesene, and germacrene $D$ in the essential oil; however, neither of the treatments increased the concentration of carvone, the main essential oil constituent of 'Native' spearmint oil.
\end{abstract}

'Native' spearmint, Mentha spicata L., is one of the two widely grown spearmints in the United States and throughout the

Received for publication 4 Jan. 2013. Accepted for publication 5 Mar. 2013.

This research was funded by the University of Wyoming startup funding awarded to Dr. V. Zheljazkov and in part by the SunGrant Initiative Program, project title "Development of Production Systems for Emerging Feedstock for Double Utilization," awarded to Dr. Zheljazkov.

We thank Mr. Bradley Wood, Mr. Lyn Ciampa, and Mr. Jeremiah Vardiman for their help with the field trials and Ms. Sydney Waggener for her help with the oil extraction.

${ }^{1}$ To whom reprint requests should be addressed; e-mailvjeliazk@uwyo.edu, Valtcho.pubs@gmail. com. world (Bienvenu et al., 1999; Lawrence, 2006; Topalov, 1989). The other spearmint is 'Scotch' spearmint, which actually is a different species (Mentha $\times$ gracilis Sole.; syn. $M$. cardiaca L.). 'Native' spearmint is a major essential oil crop grown in the Midwest and in the northwestern United States (National Agricultural Statistic Service, 2009). However, 'Native' spearmint has a wide environmental adaptation, and recent studies demonstrated feasibility of growing it under the humid conditions of Mississippi (Zheljazkov et al., 2010a, 2010b, 2012a). Indeed, the natural distribution of Mentha spicata L. spans from Alaska and British Columbia to Texas and Florida in North America [U.S. Department of Agriculture (USDA), 2012].
Recent studies in Wyoming indicated that 'Native' spearmint can withstand the first fall frost and apparently could be developed as a crop for northern Wyoming at $1170 \mathrm{~m}$ a.s.l. elevation (Zheljazkov et al., 2012a). Developing means for increased biomass and oil yields and increased concentrations of carvone, the main essential oil constituent of 'Native' spearmint, would be beneficial for the existing and future spearmint essential oil industry. There have been various studies aiming to improve essential oil yield and composition of spearmints. For example, previous studies demonstrated that some plant hormones such as MJ may increase carvone concentration of 'Scotch' spearmint (Zheljazkov and Astatkie, 2011a). In another study, the application of MJ had no significant effect on essential oil content of 'Native' spearmint (Zheljazkov et al., 2010 b). In the same study, the application of distillation water from wild bergamot (bee balm) (Monarda fistulosa L.) increased the essential oil content, whereas the distillation water of absinthe wormwood (Artemisia absinthium L.), lavender (Lavandula vera $\mathrm{DC}$ ), and wild bergamot increased oil yields of 'Native' spearmint (Zheljazkov et al., 2010b). In other studies, it was shown that plant hormones or plant extracts may have a significant effect on spearmint and peppermint essential oil yields and composition (Zheljazkov and Astatkie, 2011b, 2012). These reports suggest that MJ and some plant extracts may have potential for improving spearmint oil content and composition.

Rocky mountain juniper (Juniperus scopulorum Sarg.) and big sagebrush (Artemisia tridentata Nutt.) are two of the most widely spread native plants in the semiarid regions of western United States, Mexico, and Canada (USDA, 2011). These species provide cover for a number of wildlife species and food for many birds, whitetail deer, elk, bighorn sheep, pronghorn antelope, but also for cattle and sheep (Scher, 2002). Both species contain a significant amount of plant secondary metabolites. Rocky Mountain juniper contains podophyllotoxin and essential oil (Cantrell et al., 2013; Zheljazkov et al., 2013). Big sagebrush contains essential oil, MJ (Jassbi et al., 2010), and other plant chemicals. Junipers and sagebrush have been shown to exert allelopathic effects on surrounding species (Jassbi et al., 2010; Preston et al., 2002; Yager and Smeins, 1999). On the other hand, Tween 20 has also been investigated as a means for improving essential oil content of some aromatic plants (Dobreva et al., 2011).

There are no studies in the literature whether foliar application of Rocky Mountain juniper or sagebrush extracts could modify essential oil content and composition of spearmints. The hypothesis of this study was that Rocky Mountain juniper and sagebrush essential oil and plant extracts may have significant effect on essential oil yields, content, and composition of 'Native' spearmint grown under Wyoming conditions. 


\section{Materials and Methods}

Field experiments. 'Native' spearmint was used in this field experiment. The spearmint plantation was established on 28 June 2011 at the Sheridan Research and Extension Center Experimental Fields next to Sheridan College at lat. $44^{\circ} 45.686^{\prime} \mathrm{N}$ and long. $-106^{\circ} 55.479^{\prime} \mathrm{W}$ at an elevation of 1171 $\mathrm{m}$ above sea level. The soil at the experimental site was Wyarno clay loam, $\mathrm{pH}$ 6.8, 1.5\% organic matter content, and $1.15 \mathrm{~g} \cdot \mathrm{cc}^{-1}$ bulk density; the slope was $\approx 1 \%$. Certified virusfree 'Native' spearmint was purchased from the Summit Plant Laboratories, Inc. (Fort Collins, CO). Plantlets were grown in a greenhouse for 4 weeks until they reached 10 to $12 \mathrm{~cm}$ height and then were transplanted into low-level raised beds.

Before bed preparation, the land was disked several times, and preparation of beds (12 $\mathrm{cm}$ high, $80 \mathrm{~cm}$ across) was by a presspan-type of bed-shaper machine. The bed shaper also placed a drip-tape irrigation tube in the middle of each bed, 5 to $6 \mathrm{~cm}$ deep. The weed control during the first and the second years was conducted with Sinbar (Terbacil $80 \%$ WP) (DuPont, Wilmington, DE) at $2 \mathrm{~kg} \cdot \mathrm{ha}^{-1}$. Spearmint plants were handtransplanted in two rows on each bed, at $30 \mathrm{~cm}$ between plants in each row, with interrow spacing of $30 \mathrm{~cm}$. Spearmint plants were watered through the drip-tape irrigation system for the period of 1 June to 15 Oct. 2012, once a week, calculated to provide $2.5 \mathrm{~cm}$ water/week through the drip tape $(0.2 \mathrm{~mm}$, emitters spaced at $30 \mathrm{~cm}$, $\left.1703 \mathrm{~cm}^{3} / \mathrm{min} / 30.5 \mathrm{~m}\right)$. Ammonium nitrate was applied after transplanting at $180 \mathrm{~kg}$ nitrogen/ha.

The treatments were: 1) water (control); 2) water + Tween 20;3) sagebrush essential oil + Tween20; 4) SWE; 5) juniper EO oil + Tween20; 6) JWE; and (7) MJ. All of the treatments were applied three times as foliar application: 1) on 22 June 2012; 2) 3 July 2012; and 3) 9 July 2012 by hand spraying with mister bottles. Fifty milliliters of solution were applied to $3 \mathrm{~m}^{2}$ of each plot.

The water extract stock solutions for spraying were prepared as follows: Rocky Mountain juniper and big sagebrush dry samples were chopped in $5-\mathrm{cm}$ pieces. Extracts were prepared by adding $2 \mathrm{~L}$ of boiling water to $250 \mathrm{~g}$ of juniper or sagebrush air-dried plant material and left to soak overnight. The next morning the extracts were filtered through triple cheesecloth to remove plant residue.

The Rocky Mountain juniper and big sagebrush EOs used to prepare the respective essential oil stock solutions were derived by steam distillation as described previously (Zheljazkov et al., 2012a, 2012b). The EO solutions were prepared using $5 \mathrm{~mL}$ of either sagebrush or juniper oil plus $5 \mathrm{~g}$ of Tween 20 dissolved in $1 \mathrm{~L}$ water. The MJ (SigmaAldrich, St. Louis MO) solution included $0.105 \mathrm{~mL}$ in $1 \mathrm{~L}$ water. Once prepared, all solutions were stored in a refrigerator at 4 to $5{ }^{\circ} \mathrm{C}$ until needed.
The sagebrush EO included the following major constituents: alpha-pinene, camphene, eucalyptol, chrysanthenone, transpinocarvone, camphor, fragranol, transalpha-necrodol-acetate, grandisol, and the following minor (below $1 \%$ of the oil) constituents: hexanal, tricyclene, sabinene, beta-pinene, alpha-terpinene, paracimene, limonene, cis-thujone, pinocarvone, borneol, beta-caryophyllene, gammacurcumene, and few others (Zheljazkov, personal communication). The Rocky Mountain juniper oil contained the following constituents: sabinene (major constituent), alpha-thujene, alpha-pinene, camphene, beta-pinene, myrcene, alpha-terpinene, paracymene, limonene, gammaterpinene, cis-sabinene hydrate, terpinolene, 4-terpinenol, pregeijerene-B, gamma-muurolene, delta-cadinene, elemol, alpha-eudesmol/ beta eudesmol, and 8-alpha-acetoxyelemol (Zheljazkov et al., 2012b).

Spearmint plants from all plots were harvested at the same time, on 12 July 2012 , with a hedge trimmer. From each plot, $1.83 \mathrm{~m}^{2}$ was harvested, and the fresh weight and oil yield values were converted to $\mathrm{kg} \cdot \mathrm{ha}^{-1}$ before data analysis. All plants were cut at 4 to $5 \mathrm{~cm}$ above the soil surface. Fresh herbage yields were taken immediately. Spearmint EO was extracted from $500 \mathrm{~g}$ fresh samples using steam distillation in 2-L steam distillation units for $60 \mathrm{~min}$ as described previously (Gawde et al., 2009; Zheljazkov et al., 2010a, 2010b). After separation from water, all EOs were measured on an analytical scale and kept in a freezer at $-14{ }^{\circ} \mathrm{C}$ until the commencement of analyses. The EO oil content was calculated as grams of oil per $100 \mathrm{~g}$ of fresh herbage.

Gas chromatography of spearmint essential oils. The spearmint EO samples (all in three replicates from each treatment) were analyzed on a Hewlett Packard gas chromatograph (GC) model 6890. The GC was fitted with an autosampler. The carrier gas was helium, $40 \mathrm{~cm} \cdot \mathrm{sec}^{-1}, 11.7 \mathrm{psi}\left(60^{\circ} \mathrm{C}\right), 2.5 \mathrm{~mL} \cdot \mathrm{min}^{-1}$ constant flow rate; the injection was split 60:1 with $0.5 \mu \mathrm{L}$, the injector temperature was $220^{\circ} \mathrm{C}$; the oven temperature program was $60{ }^{\circ} \mathrm{C}$ for $1 \mathrm{~min}, 10^{\circ} \mathrm{C} / \mathrm{min}$ to $250^{\circ} \mathrm{C}$. The GC was fitted with a HP-INNOWAX column (crosslinked polyethylene glycol; $30 \mathrm{~m} \times 0.32 \mathrm{~mm} \times 0.5 \mu \mathrm{m}$ ), and the flame ionization detector temperature was $275^{\circ} \mathrm{C}$.

Statistical analysis. The effect of the foliar application treatments on EO content, fresh weight, oil yield, and the concentrations of beta-pinene, myrcene, limonene, eucalyptol, cis-sabinene hydrate, 4-terpineol, neo-dihydro carveol/cis-dihyd, cis-carveol, carvone, betacaryophyllene, trans-beta-farnesene, and germacrene $\mathrm{D}$ was determined through analysis of variance (ANOVA) of a completely randomized design with three replications (Montgomery, 2013). The ANOVA of all these response measurements was completed using the GLM Procedure of SAS (SAS Institute Inc., 2010), and further multiple means comparison was completed when treatment effect was significant $(P<0.05)$ or marginally significant $(0.05<P<0.1)$. The multiple means comparison method (Montgomery, 2013) used was the
Duncan's multiple range test at the 5\% level of significance. For each response, the validity of model assumptions on the error terms, namely normal distribution and constant variance, was verified by examining the residuals as described in Montgomery (2013). The randomization done during the experiment assures the third (independence) assumption on the error terms.

\section{Results}

Treatments significantly affected the EO content, fresh weight, and the concentrations of carvone, beta-caryophyllene, trans-betafarnesene, and germacrene $\mathrm{D}$ in the EOs (Table 1). Among all treatments the EO content was lowest in the water + Tween 20 and in juniper $\mathrm{EO}+$ Tween 20 treatments and highest in the juniper water extract and in $\mathrm{MJ}$ treatments; the rest were not significantly different from one another (Table 2). Biomass fresh weight was reduced in the SWE and in the JWE relative to the water control (Table 2). However, the treatments did not have an effect on oil yields (averaged 82.1 $\mathrm{kg} \cdot \mathrm{ha}^{-1}$ ) and on the concentrations of betapinene $(0.82 \%$ average), myrcene $(3.3 \%$ average), limonene (12.7\% average), eucalyptol (1.3\% average), cis-sabinene hydrate (1.6\% average), 4 -terpineol (1.1\% average), neo-dihydro carveol ( $2.2 \%$ average), and on cis-carveol $(5.7 \%$ average) (Table 1$)$.

The application of juniper EO + Tween 20 reduced the concentration of carvone in the oil relative to the water control or to the water + Tween 20 treatments. The SWE, juniper EO + Tween20, juniper water extract, and MJ increased the concentrations of beta-caryophyllene relative to the water treatment. The concentration of trans-beta-farnesene was lower in

Table 1. Analysis of variance $P$ values that show the significance of the effect of treatment on essential oil content, fresh weight, oil yield, and the concentrations of beta-pinene, myrcene, limonene, eucalyptol, cis-sabinene hydrate, 4-terpineol, neo-dihydro carveol/cis-dihyd, ciscarveol, carvone, beta-caryophyllene, transbeta-farnesene, and germacrene $\mathrm{D} .{ }^{\mathrm{z}}$

\begin{tabular}{lcc}
\hline Response & $P$ value & Mean \\
\hline Essential oil content & $0.082^{\mathrm{y}}$ & \\
Fresh weight & 0.044 & \\
Oil yield & 0.166 & $82.1 \mathrm{~kg} \cdot \mathrm{ha}^{-1}$ \\
Beta-pinene & 0.521 & $0.82 \%$ \\
Myrcene & 0.523 & $3.3 \%$ \\
Limonene & 0.798 & $12.7 \%$ \\
Eucalyptol & 0.822 & $1.3 \%$ \\
Cis-sabinene hydrate & 0.504 & $1.6 \%$ \\
4-terpineol & 0.805 & $1.1 \%$ \\
Neo-dihydro carveol/ & 0.331 & $2.2 \%$ \\
$\quad$ cis-dihyd & & \\
Cis-carveol & 0.566 & $5.7 \%$ \\
Carvone & 0.035 & \\
Beta-caryophyllene & 0.042 & \\
Trans-beta-farnesene & 0.013 & \\
Germacrene D & 0.044 & \\
\hline
\end{tabular}

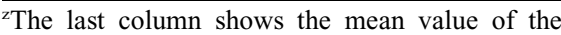
responses that were not significantly affected by the treatments.

${ }^{\mathrm{y}}$ The means of the responses significantly affected by the treatments are shown in Table 2 . 
Table 2. Means together with letter groupings of essential oil (EO) content $(\%)$, fresh weight $\left(\mathrm{kg} \cdot \mathrm{ha}^{-1}\right)$, and the concentrations $(\%$ of the total oil) of carvone, betacaryophyllene, trans-beta-farnesene, and germacrene D obtained from the seven foliar application treatments. ${ }^{z}$

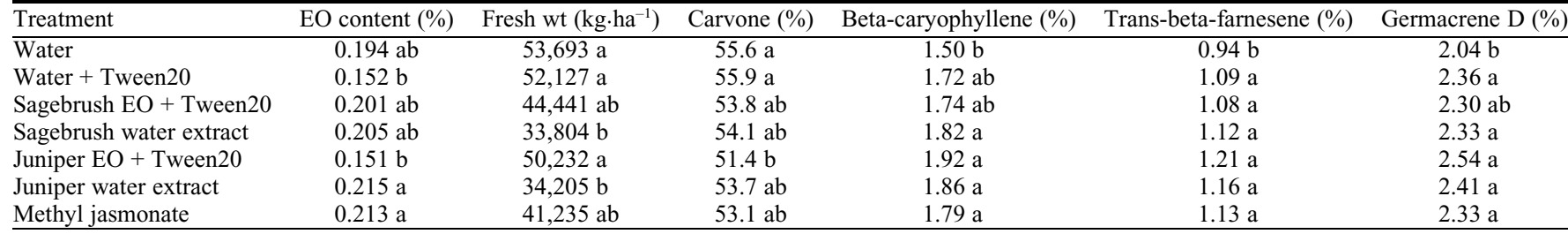

${ }^{2}$ Within each column, means followed by the same letter are not significantly different using Duncan's multiple range test at the $5 \%$ level of significance.

the control water treatment and higher in all other treatments. The concentration of germacrene $\mathrm{D}$ was low in the control water treatment and high in all other treatments except in the sagebrush EO + Tween20 treatment, which was not significantly different (Table 2).

\section{Discussion}

In this study, the application of juniper $\mathrm{EO}+$ Tween20 and the application of MJ reduced the concentration of carvone in the oil relative to the water control. The suppressive effect of MJ on carvone is contrary to another report, in which MJ application increased the concentration of carvone in 'Scotch' spearmint, Mentha $\times$ gracilis Sole. (Zheljazkov and Astatkie, 2011a). However, in a report by Zheljazkov and Astatkie (2011b), in which MJ was applied to another spearmint species, grown under controlled environment conditions, suggested that the effects of MJ application on EO content may be different in different spearmint species. Furthermore, in the report of Zheljazkov and Astatkie (2011b), the application of MJ at $100 \mathrm{mg} \cdot \mathrm{L}^{-1}$ decreased the concentrations of beta-caryophyllene and of germacrene $\mathrm{D}$, an action that is opposite to the observed effects in this study. In this study, MJ did not affect biomass fresh weight or EO content, whereas in a previous study, salicylic acid increased the biomass yields of 'Native' spearmint and 'Black Mitcham' peppermint (Zheljazkov et al., 2010b).

In this study, the concentration of carvone in the EO fluctuated from $51.4 \%$ to $55.9 \%$, which is within the range of carvone concentration in the same 'Native' spearmint in a previous study in Wyoming (Zheljazkov et al., 2012a). The EO profile of 'Native' spearmint in this study was similar to the ones previously reported for other regions of the United States (Lawrence, 2006; Murray et al., 1972; Zheljazkov et al., 2010a) or regions outside the United States (Bienvenu et al., 1999; Chowdhury et al., 2007; Kizil and Toncer, 2006; Sokovic et al., 2009; Topalov, 1989). For example, in an earlier study in Indiana and Michigan in the 1970s by Murray et al. (1972), the concentration of carvone in 'Native' spearmint oils fluctuated from $58 \%$ to $68 \%$. In a review paper on carvone, de Carvalho and Da Fonseca (2006) stated that overall, the concentration of carvone in spearmint oils should be above $50 \%$; in most cases, it would be even higher, between $60 \%$ and $70 \%$. In a recent study in Mississippi with the same cultivar of spearmint, Zheljazkov et al. (2010a) found the variation of carvone concentration in the oils to be $59 \%$ to $62 \%$ at one of the locations in Verona, MS, and $68 \%$ to $74 \%$ at Stoneville, MS. These differences are probably the result of differences in environmental conditions between Mississippi and Wyoming, because in both studies, the same cultivar, Native, of spearmint was used.

This study demonstrated that foliar application of sagebrush EO, SWE, juniper EO, or JWE to 'Native' spearmint may affect the EO composition of spearmint. Some of the treatments increased the concentrations of beta-caryophyllene, trans-beta-farnesene, and germacrene D in the EO; however, neither of the treatments increased the concentration of carvone, the main EO constituent of 'Native' spearmint oil.

\section{Literature Cited}

Bienvenu, F., L. Peterson, and J. Edwards. 1999 Native and Scotch spearmint oil production in Tasmania and Victoria. A report for Rural Industries Research and Development Corporation. Publ. \#99/147, Project \#DAV-101A, p32. 7 Feb. 2013. <https://rirdc.infoservices.com.au/ downloads/99-147>.

Cantrell, C.L., V.D. Zheljazkov, W.A. Osbrink, A. Castro, V. Maddox, L.E. Craker, and T. Astatkie. 2013. Podophyllotoxin and essential oil profile of Juniperus and related species. Ind. Crops Prod. 43:668-676.

Chowdhury, J.U., N.C. Nandi, M. Uddin, and M. Rahman. 2007. Chemical constituents of essential oils from two types of spearmint (Mentha spicata L. and M. cardiaca L.) introduced in Bangladesh. Bangl. J. Sci. Indus. Res. 42:79-82.

de Carvalho, C.C.C.R. and M.M.R. Da Fonseca 2006. Carvone: Why and how should one bother to produce this terpene. Food Chem. 95:413-422.

Dobreva, A., N. Kovatcheva, T. Astatkie, and V.D. Zheljazkov. 2011. Improvement of essential oil yield of oil-bearing rose (Rosa damascena Mill.) due to surfactant and maceration. Ind. Crops Prod. 34:1649-1651.

Gawde, A.J., C.L. Cantrell, and V.D. Zheljazkov. 2009. Dual extraction of essential oil and podophyllotoxin from Juniperus virginiana. Ind. Crops Prod. 30:276-280.

Jassbi, A.R., S. Zamanizadehnajari, and I.T. Baldwin. 2010. Phytotoxic volatiles in the roots and shoots of Artemisia tridentata as detected by headspace solid-phase microextraction and gas chromatographic-mass spectrometry analysis. J. Chem. Ecol. 36:1398-1407.
Kizil, S. and O. Toncer. 2006. Influence of different harvesting times on the yield and oil composition of spearmint (Mentha spicata L. var. spicata). J. Food Agr. Environ. 4:135-137.

Lawrence, B.M. 2006. Mint: The genus Mentha. CRC Press, Boca Raton, FL.

Montgomery, D.C. 2013. Design and analysis of experiments. 8th Ed. Wiley, New York, NY.

Murray, M.J., W. Faas, and P. Marble. 1972. Effects of plant maturity on oil composition of several spearmint species grown in Indiana and Michigan. Crop Sci. 12:723-728.

National Agricultural Statistic Service. 2009. Dec. 2012. <http://www.nass.usda.gov/Statistics_by_ State/Oregon/Publications/Field_Crop_Report/ crop\%20reports/01_13an.pdf>.

Preston, C.A., H. Betts, and I.T. Baldwin. 2002 Methyl jasmonate as an allelopathic agent: Sagebrush inhibits germination of a neighboring tobacco, Nicotiana attenuata. J. Chem. Ecol. 28:2343-2369.

SAS Institute Inc. 2010. SAS/STAT ${ }^{\circledR} 9.3$ user's guide. SAS Institute Inc., Cary, NC.

Scher, J.S. 2002. Juniperus scopulorum. In: Fire Effects Information System [Online]. U.S. Department of Agriculture, Forest Service, Rocky Mountain Research Station, Fire Sciences Laboratory (producer). Mar. 2013. <http:// www.fs.fed.us/database/feis/plants/tree/junsco/ all.html $>$.

Sokovic, M.D., J. Vukojevic, P.D. Marin, D.D. Brkic, V. Vajs, and L.J.L.D. van Griensven. 2009. Chemical composition of essential oils of Thymus and Mentha species and their antifungal activities. Molecules 14:238-249.

Topalov, V.D. 1989. Mentha, p. 372-381. In: Topalov, V.D., I.I. Dechev, and M.S. Pehlivanov (eds.). Plant production. Zemizdat Press, Sofia, Bulgaria.

U.S. Department of Agriculture. Natural Resources Conservation Service, Plants profile: Juniperus scopulorum Sarg., Rocky Mountain juniper. 2011. Mar. 2013. <http://plants.usda.gov/ java/profile? symbol $=$ JUSC2 $>$.

U.S. Department of Agriculture. Natural Resources Conservation Service. 2012. Plants database. Mentha spicata L., spearmint. Dec. 2012. $<$ http://plants.usda.gov/java/profile?symbol= Mesp3>.

Yager, L.Y. and F.E. Smeins. 1999. Ashe juniper (Juniperus ashei: Cupressaceae) canopy and litter effects on understory vegetation in a juniper-oak savanna. Southwest. Nat. 44:6-16.

Zheljazkov, V.D. and T. Astatkie. 2011a. Effect of residual distillation water of 15 plants and three plant hormones on Scotch spearmint (Mentha $\times$ gracilis Sole). Ind. Crops Prod. 33:704-709.

Zheljazkov, V.D. and T. Astatkie. 2011b. Effect of distillation waste water and plant hormones on spearmint growth and composition. J. Sci. Food Agr. 91:1135-1141

Zheljazkov, V.D., C.L. Cantrell, T. Astatkie, and M.W. Ebelhar. 2010a. Productivity, oil 
content and composition of two spearmint species in Mississippi. Agron. J. 102:129-133.

Zheljazkov, V.D., T. Astatkie, T. Horgan, and S.M. Rogers. 2010b. Effect of plant hormones and distillation water on mints. HortScience 45:1338-1340.

Zheljazkov, V.D., C.L. Cantrell, T. Astatkie, and E. Jeliazkova. 2012a. Fall frosts effects on the essential oil of "Native" spearmint in Wyoming. HortScience 47:16031606.

Zheljazkov, V.D., T. Astatkie, E.A. Jeliazkova, and V. Schlegel. 2012b. Distillation time alters essential oil yield, composition, and antioxidant activity of male Juniperus scopulorum trees. J. Oleo Sci. 61:537-546.
Zheljazkov, V.D. and T. Astatkie. 2012. Distillation waste water can modify peppermint (Mentha $\times$ piperita L.) oil composition. Ind. Crops Prod. 36:420-426.

Zheljazkov, V.D., C.L. Cantrell, M.A. Donega, and T. Astatkie. 2013. Bioprospecting for podophyllotoxin in the Big Horn Mountains, Wyoming. Ind. Crops Prod. 43:787-790. 